J-DEPACE, Vol. 1, No. 1, Desember 2018, Hal 42 - 54

Tersedia online di :http://jurnal.lpmiunvic.ac.id/index.php/jpkm

\title{
KONSEP PENGEMBANGAN EKOWISATA BERBASIS KONSERVASI DI KAMPUNG MALAGUFUK KABUPATEN SORONG
}

\author{
Maya Pattiwael* \\ Program Studi Kehutanan Fakultas Ilmu Pertanian dan Lingkungan \\ Universitas Victory Sorong \\ *mayapattiwael@yahoo.com
}

\begin{abstract}
ABSTRAK
Dampak negatif dari kegiatan ekowisata terhadap hutan alam dapat diatasi dengan pemberdayaan masyarakat lokal dalam kegiatan ekowisata yang berbasis konservasi agar kelestarian sumberdaya alam yang ada pada daerah tersebut dapat terus dijaga. Pengabdian masyarakat yang dilakukan di Kampung Malagufuk berupa sosialisasi tentang pengembangan ekowisata berbasis konservasi bertujuan untuk meningkatkan pemahaman dan kesadaran masyarakat Kampung Malagufuk tentang pentingnya menjaga kekayaan sumberdaya alam yang ada pada hutan alam Klasow agar tidak disalahgunakan atau dirusak oleh para pengunjung. Penerapan prinsip dan konsep pengembangan ekowisata berbasis konservasi berupa kelestarian fungsi ekosistem, kelestarian obyek daya tarik wisata alam, kelestarian sosial budaya, kepuasan, keselamatan, dan kenyamanan pengunjung, sertaprinsip manfaat ekonomi. Hasil akhir dari kegiatan pengabdian ini berupa penanaman bibit pohon sebagai bukti kepedulian terhadap konservasi dan mendapat dukungan yang baik dari masyarakat setempat.
\end{abstract}

Kata kunci : ekowisata, konservasi

\section{ABSTRACT}

The negative impact of ecotourism activities on natural forests can be overcome by empowering local communities in ecotourism activities based on conservation, so that the sustainability of natural resources in the area can be maintained. Community service carried out in Malagufuk Village is a socialization of ecotourism development based on conservation which aims to increase the understanding and awareness of the Malagufuk Village community about the importance to keep nature resources properties that exist in Klasow natural forests so as not to be misused or damaged by visitors. Application of the principles and concepts of ecotourism development based on conservation, in the form of ecosystem function sustainability, natural tourist attraction objects sustainability, socio-cultural sustainability, satisfaction, safety, and visitor comfort, along with the principle of economic benefits. The end result of this service activity is planting tree seedlings as evidence of concern for conservation and getting support from the local community.

Keywords : Ecotourism, Conservation 


\section{PENDAHULUAN}

Awal munculnya ekowisata selalu diwarnai dengan adanya dampak kerusakan lingkungan. Salah satu contoh adalah kegiatan perburuan hewan di alam bebas yang terjadi pada awal tahun 1900 di Kenya. Pemerintah Kenya menjual satu ekor singa sebagai buruan seharga US\$27.000 pada tahun 1970. Namun akhirnya disadari bahwa perburuan yang tidak terkendali dapat mengakibatkan kepunahan spesies flora atau fauna dan mengganggu keseimbangan ekosistem yang ada. Berdasarkan pengalaman tersebut, pemerintah Kenya akhirnya melakukan banyak perubahan dan mulai menerapkan konsep-konsep ekowisata modern di dalam industri pariwisata. Di Indonesia kegiatan ekowisata mulai dirasakan pada pertengahan tahun 1980-an. Pariwisata massal yang terjadi sekitar tahun tersebut terbukti menimbulkan kepunahan bagi beberapa spesies hewan maupun flora (Fandeli, 2002). Belajar dari adanya kesalahan-kesalahan terdahulu, maka ekowisata mulai dipahami dan dijalankan dengan tujuan pelestarian sumber daya alam dan melibatkan masyarakat untuk berperan aktif dalam menjaga lingkungannya, yang sekaligus berimbas pada meningkatnya pendapatan masyarakat setempat.

Ekowisata dapat diartikan sebagai perjalanan seorang turis ke daerah terpencil untuk melakukan kegiatan wisata, yang tujuan menikmati dan mempelajari mengenai alam, sejarah dan budaya di suatu daerah, dengan tetap mengutamakan kelestarian sumber daya alam dan lingkungan, sehingga spesies yang ada dapat tetap terpelihara dalam habitatnya serta membantu meningkatkan perekonomian masyarakat lokal (Goodwin, 1997 dalam Sastrayuda, 2010 ; Anonim, 2009). Ekowisata menurut The International Ecotourism Society dalam Priono (2012) merupakan perjalanan yang bertanggungjawab ke daerah-daerah alami yang melestarikan lingkungan, menopang kesejahteraan masyarakat setempat, melibatkan interpretasi serta pendidikan lingkungan hidup.

Di Papua Barat khususnya di Kabupaten Sorong terdapat daerah-daerah yang cocok untuk dijadikan lokasi ekowisata. Salah satu wilayah yang dimaksud adalah Kampung Malagufuk yang baru mulai ditempati pada akhir tahun 2014 atau kurang lebih 4 tahun yang lalu. Kampung Malagufuk memilik hutan alam yang disebut Hutan Klasow. Sebagai kawasan baru, hutan alam Klasow tentunya masih alami dan jauh dari kerusakan hutan. Berbagai jenis vegetasi maupun satwa ada pada kawasan tersebut, bahkan jenis endemik juga bisa ditemui. Dengan demikian, daerah tersebut dapat dikatakan masih memiliki nilai keanekaragaman yang cukup tinggi, sehingga kelestariannya harus tetap dijaga. Meskipun termasuk wilayah 
baru, Kampung Malagufuk sering dikunjungi oleh para wisatawan, baik dalam negeri maupun luar negeri, yang memiliki ketertarikan untuk melakukan pengamatan terhadap satwa, khususnya berbagai jenis burung yang ada di daerah tersebut.

Menurut Mackinnon (1990) dalam Qomariah (2009) bahwa keberhasilan pengelolaan banyak bergantung pada kadar dukungan dan penghargaan yang diberikan kepada kawasan yang dilindungi oleh masyarakat disekitarnya. Berdasarkan hal tersebut, maka untuk mengurangi dampak negatif dari kegiatan ekowisata terhadap hutan alam oleh para pengunjung, maka pemberdayaan masyarakat lokal dalam kegiatan ekowisata yang berbasis konservasi perlu dilakukan agar kelestarian sumberdaya alam yang ada pada daerah tersebut dapat terus dijaga. Pemberdayaan masyarakat lokal dalam kegiatan ekowisata selain untuk konservasi sumberdaya alam juga dapat meningkatkan perekonomian masyarakat tersebut.

Dalam upaya pengembangan ekowisata yang berbasis konservasi pada hutan alam Klasouw sekaligus peningkatan perekonomian masyarakat lokal, maka perlu dilakukan kegiatan sosialisasi untuk memberikan pemahaman bagi masyarakat tentang ekowisata dan upaya konservasi yang perlu dilakukan. Pemberdayaan masyarakat lokal diharapkan dapat bermanfaat untuk menjaga keanekaragaman hayati yang ada pada hutan alam Klasow dan juga meningkatkan perekonomian masyarakat pada Kampung Malagufuk.

\section{MASALAH}

Kampung Malagufuk merupakan Kampung pemekaran dari Kampung Malaumkarta Kabupaten Sorong, yang mulai dibentuk pada akhir tahun 2014. Sebagai Kampung yang baru dimekarkan, Malagufuk masih sangat jarang dikunjungi. Berdasarkan hasil wawancara dengan Kepala kampung, diketahui bahwa masyarakat Kampung Malagufuk belum pernah mendapatkan sosialisasi atau penyuluhan yang berhubungan dengan Ekowisata. Oleh sebab itu, pengetahuan tentang ekowisata dan konservasi itu sendiri masih sangat kurang.

Berdasarkan permasalahan tersebut, maka dilakukan pengabdian masyarakat berupa sosialisasi tentang ekowisata berbasis konservasi di Kampung Malagufuk Kabupaten Sorong. Maksud dari kegiatan ini adalah untuk mengedukasi masyarakat di Kampung Malagufuk tentang manfaat positif dari ekowisata dan pentingnya upaya konservasi pada Hutan Alam Klasow. Program ini diharapkan dapat menjadi contoh bagi lokasi atau kawasan lainnya yang telah membuka diri terhadap kegiatan ekowisata, khususnya yang ada pada wilayah Papua Barat. 


\section{METODE}

Metode yang digunakan pada kegiatan ini adalah Pendidikan Masyarakat berupa penyuluhan tentang pengembangan ekowisata berbasis konservasi, yang bertujuan untuk meningkatkan pemahaman dan kesadaran masyarakat Kampung Malagufuk tentang pentingnya menjaga kekayaan sumberdaya alam yang ada pada hutan alam Klasow agar tidak disalahgunakan atau dirusak oleh para pengunjung.

\section{HASIL DAN PEMBAHASAN}

Kerusakan hutan merupakan masalah yang sering terjadi bahkan tidak menutup kemungkinan dapat terjadi pada kawasan yang baru dibuka. Upaya pemberdayaan masyarakat sebagai pengelola langsung kawasan yang dijadikan tujuan ekowisata, diharapkan dapat mencegah terjadinya kerusakan hutan atau kawasan tersebut. Sosialisasi yang dilaksanakan pada tanggal 13 April 2018 tersebut dapat diuraikan di bawah ini.

\subsection{Pengembangan Ekowisata Berbasis Konservasi}

\section{a. Prinsip dan kriteria pengelolaan ekowisata}

Ekowisata memiliki dampak positif bagi pengembangan suatu kawasan. Dampak positif tersebut tentunya harus diimbangi dengan keadaan alam yang terawat sehingga dapat dijadikan daya tarik bagi para wisatawan atau pengunjung. Ekowisata berbasis konservasi merupakan pengembangan ekowisata yang menitikberatkan pada pola wisata ramah lingkungan, dimana pengembangan ekowisata harus mampu memelihara, melindungi, dan bertanggung jawab terhadap pelestarian alam. Prinsip dan kriteria pengelolaan ekowisata yang dibuat oleh Badan Standarisasi Nasional (BSN) dalam Standar Nasional Indonesia (SNI 8013:2014) tentang Pengelolaan Wisata Alam, secara tidak langsung sudah mencakup konservasi. Prinsip dan kriteria tersebut dapat berupa (Supriadi, dkk., 2017) :

1. Kelestarian fungsi ekosistem

2. Kelestarian obyek daya tarik wisata alam

3. Kelestarian sosial budaya

4. Kepuasan, keselamatan, dan kenyamanan pengunjung

5. Prinsip manfaat ekonomi

Dengan mengacu pada prinsip dan kriteria yang ditetapkan BSN, maka pengembangan ekowisata akan memberikan hasil yang baik. Kelestarian fungsi 
ekosistem dalam hubungannya dengan ekowisata dapat dilakukan dengan mencegah adanya perusakan hutan oleh para pengunjung, termasuk perburuan liar dalam kawasan hutan. Dengan demikian kelestarian fungsi ekosistem tersebut dengan sendirinya akan mengarah pada kelestarian obyek dan daya tarik wisata alam, karena ekosistem yang baik dan mencerminkan keunikannya, akan menjadi daya tarik bagi pengunjung untuk datang ke tempat itu.

Kelestarian sosial budaya dapat berupa pelestarian budaya masyarakat. Dalam artian bahwa budaya masyarakat harus dijaga dengan baik. Pengunjung yang datang, baik itu wisawatan domestik maupun asing akan membawa budaya yang berbeda dengan masyarakat setempat. Oleh karena itu, masyarakat harus bisa membedakan antara hal-hal baik yang dapat diterima dan tidak dapat diterima.

Kepuasan, keselamatan dan kenyamanan pengunjung mencerminkan maksimalnya pelayanan yang diberikan oleh masyarakat setempat. Masyarakat sebagai pengelola kawasan ekowisata harus bisa memberikan jaminan bagi wisatawan tentang keselamatannya selama berada di lokasi maupun kepuasan dan kenyamanan ketika berinteraksi dengan masyarakat. Sementara itu, prinsip manfaat ekonomi lebih ditekankan pada meningkatnya pendapatan masyarakat karena adanya kunjungan dari para wisatawan. Ekowisata sendiri secara tidak langsung dapat berpengaruh positif bagi perekonomian masyarakat jika dijalankan dengan penuh rasa tanggung jawab.

\section{b. Prinsip Pengembangan Ekowisata Berbasis Masyarakat Dan Konservasi}

Pengembangan ekowisata tidak terlepas dari campur tangan masyarakat dan pada akhirnya masyarakatlah yang akan menikmati hasil dan manfaat dari ekowisata itu sendiri. Dalam kegiatan sosialisasi ini, masyarakat kampung Malagufuk diharapkan dapat menerapkan prinsip dan konsep pengembangan ekowisata berbasis konservasi yang tentunya sangat diperlukan dan secara tidak langsung dapat berpengaruh pada perekonomian masyarakat setempat. Hal tersebut disesuaikan dengan prinsip dan konsep pengembangan ekowisata oleh WWF-Indonesia (2009) dan Qomariah (2009), yaitu :

1) Keberlanjutan ekowisata dari aspek ekonomi, sosial, dan lingkungan (prinsip konservasi dan partisipasi masyarakat)

Ekowisata yang dikembangkan di kawasan konservasi adalah ekowisata yang "HIJAU dan ADIL" (Green\& Fair), yaitu sebuah kegiatan usaha yang memiliki 
kontribusi pada konservasi dengan meningkatkan kepedulian dan dukungan terhadap perlindungan bentang lahan yang memiliki nilai biologis, ekologis dan nilai sejarah yang tinggi.

Agar prinsip ini dapat berjalan dengan baik, maka daya dukung lingkungan harus diperhatikan. Hal ini pula yang ditunjukan oleh masyarakat Kampung Malagufuk. Setiap kunjungan dan kegiatan wisatawan dikelola sedemikian rupa sehingga tidak bertentangan dengan prinsip konservasi maupun sosial-budaya masyarakat setempat.

2) Pengembangan institusi masyarakat lokal dan kemitraan (prinsip partisipasi masyarakat)

Pengembangan ekowisata ini dapat dilakukan melalui kerjasama dan koordinasi yang baik antara masyarakat dengan pemerintah daerah, UPT, biro-biro perjalanan ataupun LSM. Masyarakat sebagai pemilik berperan sebagai pengelola atau stakeholder yang bisa mendapatkan keuntungan langsung dari pengembangan dan pengelolaan ekowisata ini, sehingga ekowisata bisa menjadi sumber pendapatan bagi masyarakat setempat. Berdasarkan hasil wawancara diketahui bahwa masyarakat Kampung Malagufuk telah menjalin kerjasama dengan LSM asing yang berasal dari Belanda. Hasil kerjasama tersebut berupa penyediaan air bersih bagi masyarakat Kampung Malagufuk
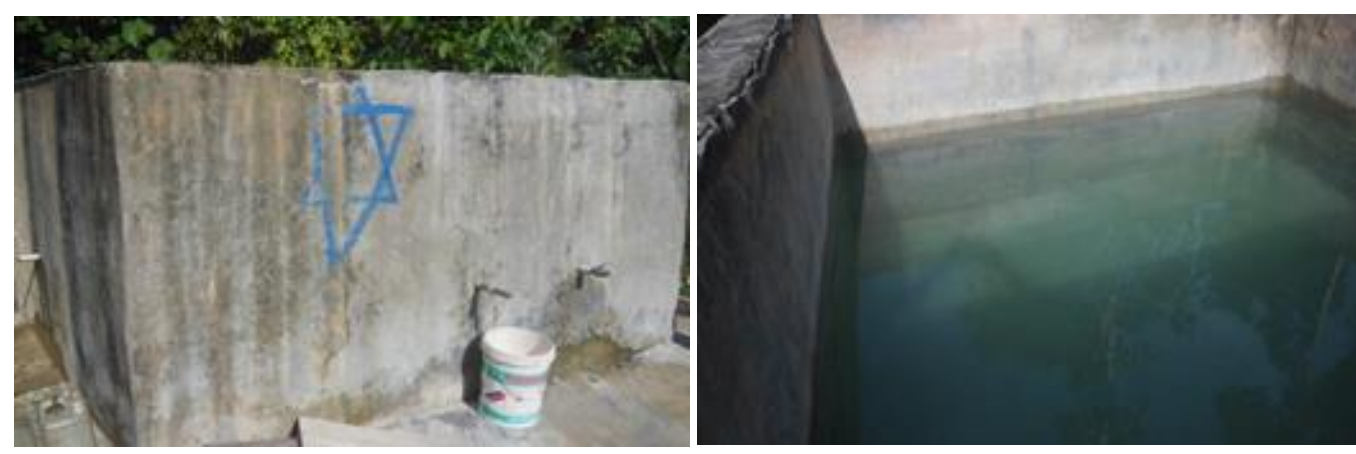

Gambar 1. Bak penampung Air Bersih

3) Ekowisata berbasis masyarakat (prinsip partisipasi masyarakat)

Istilah Guide atau pemandu sering disebutkan dalam ekowisata. Tugas dari pemandu adalah mendampingi pengunjung sampai kegiatan kunjungan itu selesai dilakukan. Hal utama yang harus dimiliki oleh pemandu adalah pengetahuan dan pengalamannya tentang lingkungan dan alam yang dikunjungi oleh wisatawan tersebut. Oleh karena itu, masyarakat lokal sangat cocok untuk pekerjaan tersebut. Selain mendapatkan keuntungan ekonomi dari ekowisata, masyarakat lokal dapat 
memiliki peran ganda yaitu sebagai Guide dan sebagai pengelola yang akan menjaga kelestarian alam dan obyek wisata.

Langkah awal pengembangan masyarakat Kampung Malagufuk adalah dengan memberikan kesempatan kepada anggota masyarakat menjadi pemandu atau pendamping bagi pengunjung. Namun karena keterbatasan dalam menggunakan Bahasa Inggris, maka pendampingan biasanya dilakukan kepada wisatawan domestik, sedangkan bagi wisatawan asing dipercayakan kepada salah satu tour leader sebagai penerjemah (dari luar Kampung Malagufuk) yang biasanya membawa wisatawan asing sebagai tamu di Malagufuk dan masyarakat tetap sebagai pendamping untuk menunjuk jalan menyusuri hutan.

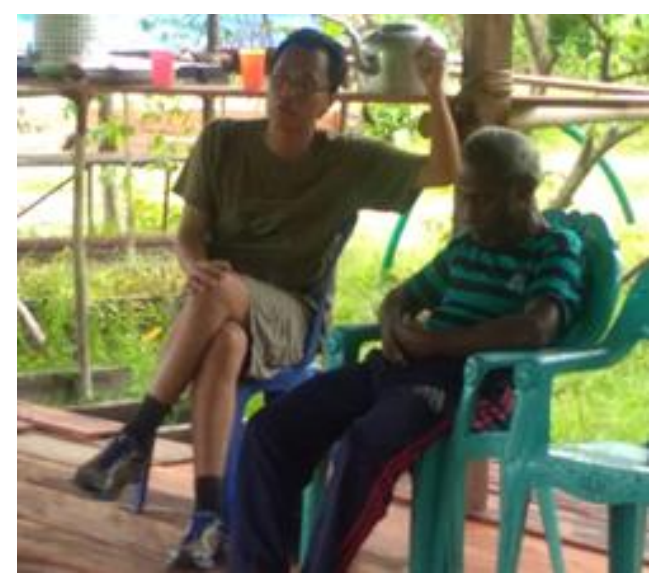

Gambar 2. Tour Leader dari Luar Kampung Malagufuk (Pak Charles sebelah kiri)

4) Prinsip edukasi dan wisata alam

Ekowisata memberikan banyak peluang untuk memperkenalkan kepada wisatawan tentang pentingnya perlindungan alam dan penghargaan terhadap kebudayaan lokal. Pada saat menikmati keindahan bentang alam di suatu lokasi, masyarakat juga secara langsung dapat mengenal flora dan fauna serta budaya masyarakat sehingga dapat menambah pengetahuan pengunjung sekaligus dapat memberikan kepuasan terhadap pemandangan yang ada. Edukasi tentang etika dan budaya masyarakat setempat perlu dituangkan dalam panduan untuk turis yang berisi tentang etika masyarakat yang perlu diikuti oleh para tamu atau turis selama berada pada wilayah ekowisata yang dikuasai oleh masyarakat setempat. 

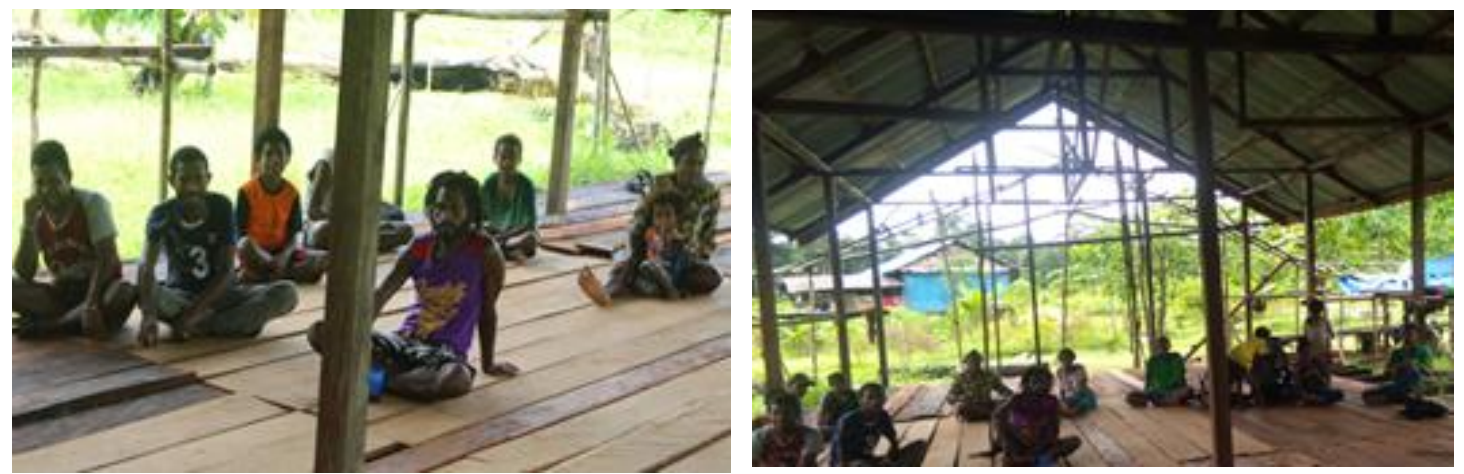

Gambar 3. Beberapa Masyarakat Kampung Malagufuk Pada Kegiatan Sosialisasi

\section{c. Kapasitas Masyarakat untuk Terlibat dalam Pengembangan Ekowisata}

Dalam menjalankan perannya sebagai pengelola kawasan ekowisata, masyarakat harus selalu terlibat secara langsung, terbuka untuk menerima setiap kunjungan dari para tamu, dan selalu siap menghadapi perubahan-perubahan yang nantinya akan terjadi pada lingkungannya. Hal tersebut sesuai dengan yang tercantum pada Guidelines for Community-Based Ecotourism Development (2001) dalam Qomariah (2009)

1) Kemampuan menjadi tuan rumah penginapan (Homestay)

Salah satu contoh akomodasi yang biasanya disediakan dalam ekowisata adalah Homestay atau rumah penginapan. Homestay yang dikelola bisa berupa penginapan sederhana yang dikelola secara langsung oleh masyarakat atau setiap keluarga bisa menyediakan rumahnya untuk ditempati oleh para tamu atau pengunjung. Selain itu, keberadaan homestay bisa memberikan keuntungan atau manfaat secara langsung bagi pemilik ataupun pengunjung. Bagi pemilik homestay bisa mendapatkan manfaat ekonomi dari kunjungan wisawatan. Sementara itu, manfaat yang didapatkan oleh wisatawan adalah kesempatan langsung untuk belajar tentang budaya masyarakat setempat. Keduanya saling tukar-menukar informasi, saling mengenal sehingga dapat menumbuhkan toleransi dan pemahaman yang lebih baik. Hal yang perlu diperhatikan adalah, budaya wisatawan terkadang tidak sama dengan budaya masyarakat setempat. Oleh karena itu, sangat diharapkan agar masyarakat mengadopsi hal-hal yang bersifat positif saja sedangkan hal-hal yang akan membawa dampak negatif sebaiknya tidak perlu diikuti.

Dari hasil pantauan di lapangan, homestay yang disediakan oleh masyarakat Kampung Malagufuk sangat layak untuk ditempati dan keadaanya disesuaikan dengan kondisi lingkungannya. Para wisatawan yang berkunjung merasa puas dengan 
pelayanan yang diberikan karena terkesan ramah dan menyenangkan, mulai dari kebersihan homestay sampai pada penyediaan makanan.

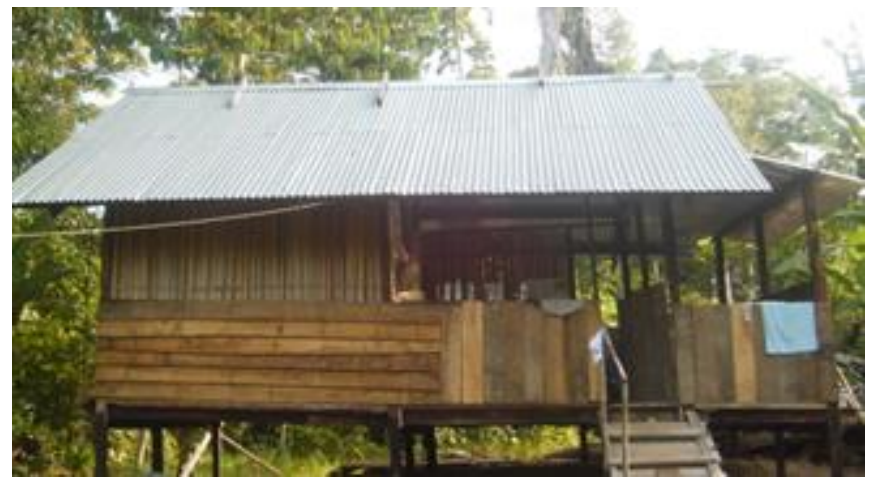

Gambar 4. Homestay di Kampung Malagufuk

2) Kemampuan dasar bahasa inggris

Kemampuan dasar masyarakat dalam Bahasa Inggris merupakan modal awal dalam menjadikan tempatnya sebagai daerah ekowisata, karena pada akhirnya tempat tersebut akan dikunjungi oleh wisawatan atau pengunjung asing (luar negeri). Kemampuan berbahasa Inggris oleh masyarakat Malagufuk dirasakan sangat terbatas. Beberapa anak yang masih duduk di bangku Sekolah Dasar (SD) secara perlahan telah diajarkan oleh Guide dari luar Kampung untuk mengenal dan mengetahui nama-nama satwa dalam Bahasa Inggris. Namun, hal tersebut belumlah cukup. Oleh karena itu, pelatihan atau kursus Bahasa Inggris perlu dilakukan agar masyarakat juga dapat menjadi Tour Guide (pemandu wisata) di daerahnya sendiri. Hal tersebut tentu saja berpengaruh juga bagi perekonomian masyarakat setempat karena biaya yang dikeluarkan oleh pengunjung akan dinikmati secara langsung oleh masyarakat yang menjadi Tour Guide.

3) Keterampilan komputer

Selain kemampuan dalam Bahasa Inggris, masyarakat juga harus memiliki keterampilan dalam mengoperasikan komputer. Minimal ada orang-orang tertentu yang telah dipercayakan untuk memiliki keterampilan ini, sehingga hal-hal yang berhubungan dengan administrasi dapat langsung ditangani. Selain itu, kegiatan promosi tentang lokasi ekowisata juga dapat dilakukan dan dipantau melalui website yang dibuat. 
4) Keterampilan pengelolaan keuangan

Keuangan merupakan hal yang sangat "sensitif" pada suatu organisasi, bahkan organisasi kecil sekalipun. Oleh karena itu, pengelolaan keuangan sebaiknya dilakukan secara terbuka dengan membuat laporan keuangan tiap bulan agar saling percaya tetap terpelihara. Setiap penerimaan maupun pengeluaran dicatat dan dilaporkan pada rapat atau pertemuan bersama. Dana yang terkumpul nantinya dapat dikelola untuk pengembangan atau perbaikan sarana dan prasarana pada lokasi ekowisata tersebut.

5) Keterampilan pemasaran

Keterampilan pemasaran berhubungan dengan kegiatan promosi yang dilakukan. Memperkenalkan atau mempromosikan suatu lokasi sebagai kawasan ekowisata merupakan agenda penting yang harus dijalankan. Kegiatan promosi perlu dilakukan lebih luas tidak hanya dari mulut ke mulut tapi dapat dilakukan melalui berbagai media, baik media cetak maupun elektronik. Kegiatan promosi tersebut dapat berupa:

a) Penyebaran leaflet, pembuatan poster maupun spanduk yang dipasang di empattempat strategis agar dapat diketahui oleh masyarakat luas

b) Promosi melalui media cetak maupun media elektronik

c) Pembaharuan informasi di web-site tiap waktu

d) Menjalin kerjasama/kemitraan dengan biro-biro perjalanan dan pihak-pihak lain yang berhubungan dengan kegiatan pariwisata

6) Keterbukaan terhadap pengunjung

Keterbukaan terhadap pengunjung yang datang merupakan faktor penting dalam pengembangan ekowisata. Keterbukaan masyarakat akan tercermin lewat pelayanan yang diberikan dan kepuasan yang dirasakan oleh pengunjung. Keterbukaan juga dapat diberikan terhadap para akademisi yang berasal dari berbagai Perguruan Tinggi di dalam daerah sendiri ataupun dari daerah lain untuk melakukan penelitian guna mempromosikan keanekaragaman hayati yang ada maupun budaya masyarakat setempat.

Persoalan penting yang belum bisa diatasi adalah mengenai transportasi dan aksesibilitas di Kampung Malagufuk. Untuk saat ini, aksesibilitas menuju Kampung Malagufuk masih sulit dijangkau karena transportasi yang biasanya digunakan oleh masyarakat maupun pengunjung hanya sampai pada jalan utama. Selanjutnya masyarakat 
dan pengunjung harus berjalan kaki menyusuri hutan sejauh $\pm 4 \mathrm{~km}$ atau 2 jam perjalanan. Oleh karena itu, pembukaan wilayah menuju Kampung Malagufuk perlu dilakukan agar arus transportasi menjadi lancar. Kegiatan ini dapat dilakukan dengan bekerjasama dengan Pemerintah Daerah. Persyaratan utama yang harus diingat dalam pembukaan wilayah adalah yang berhubungan dengan keberadaan vegetasi pada Hutan Alam Klasow yang ada di Kampung Malagufuk. Pembukaan vegetasi yang ada, dilakukan seminimal mungkin serta alat yang digunakan diupayakan tidak mengganggu keberadaan tumbuhan, satwa dan ekosistem yang ada.

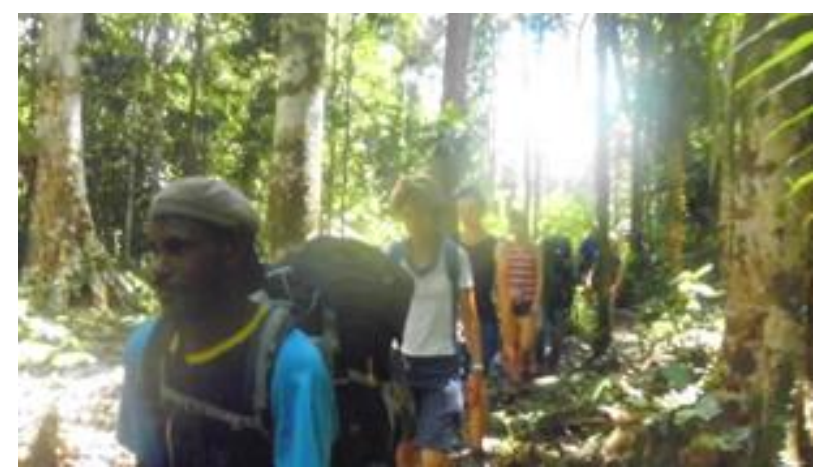

Gambar 5. Perjalanan ke Kampung Malagufuk

\subsection{Kegiatan Penanaman Bibit Pohon}

Sebagai salah satu bagian dari upaya konservasi, maka pada kegiatan Pengabdian Masyarakat ini juga dilakukan penanaman beberapa bibit pohon yang dibawa kepada masyarakat Kampung Malagufuk, yaitu pala hutan (myristica sp), durian (Durio zibethinus), rambutan (Nephelium lappaceum) dan matoa (Pometia pinnata).

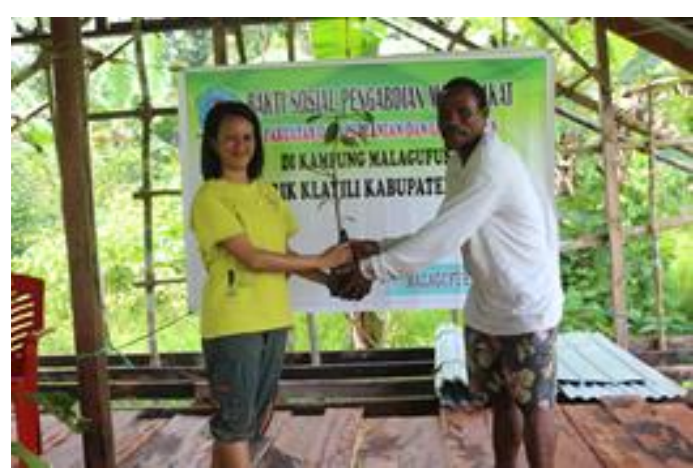

Gambar 6. Penyerahan Bibit Pohon kepada Perwakilan Masyarakat

Kegiatan penanaman ini diawali dengan penyerahan secara simbolis bibit pohon kepada sekertaris Kampung Malagufuk dan bibit pohon lainnya langsung diserahkan kepada masyarakat untuk ditanam. 

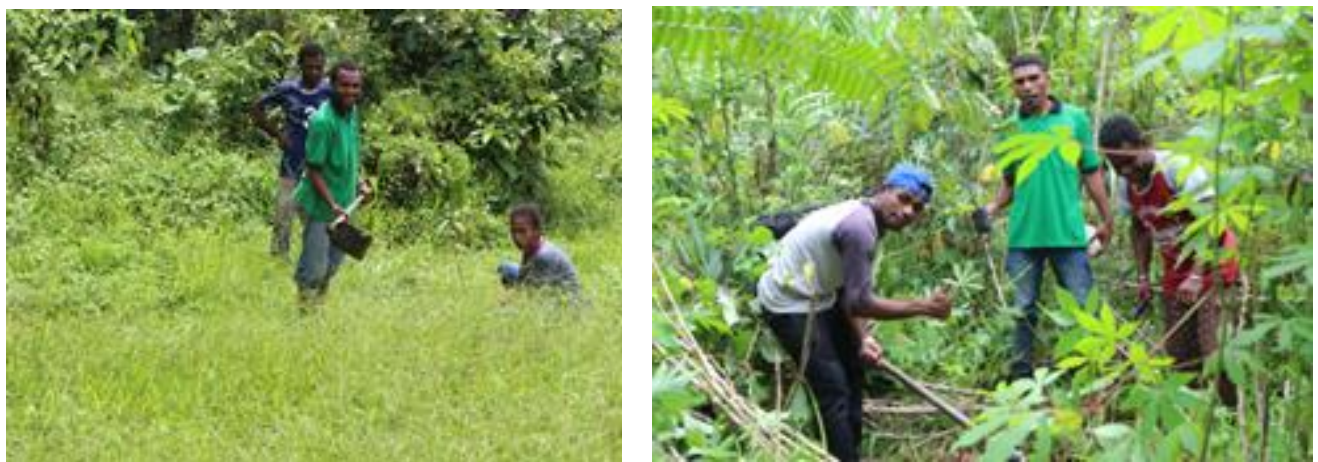

Gambar 7. Penanaman Bibit Pohon

Sebagai tindak lanjut dari kegiatan ini, diharapkan setiap anggota masyarakat dapat memelihara dan menjaga tanaman yang telah ditanam agar dapat tumbuh dengan baik dan kelak hasilnya dapat dinikmati oleh masyarakat itu sendiri.
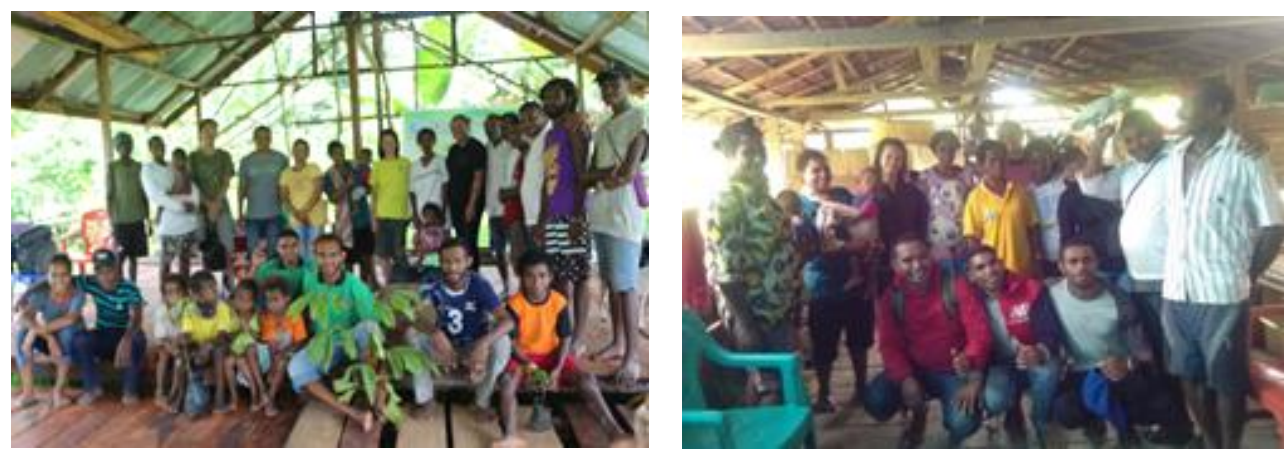

Gambar 8. Foto Bersama Masyarakat Kampung Malagufuk

\section{KESIMPULAN}

Ekowisata dapat diartikan sebagai perjalanan seorang turis ke daerah terpencil untuk melakukan kegiatan wisata, yang tujuan menikmati dan mempelajari mengenai alam, sejarah dan budaya di suatu daerah, dengan tetap mengutamakan kelestarian sumber daya alam dan lingkungan. Meskipun demikian, dampak negatif dari ekowisata bisa saja muncul karena kurangnya keterlibatan masyarakat dalam menjaga lingkungannya. Berdasarkan hal tersebut, maka untuk mengurangi dampak negatif dari kegiatan ekowisata terhadap hutan alam oleh para pengunjung, maka pemberdayaan masyarakat lokal dalam kegiatan ekowisata yang berbasis konservasi perlu dilakukan agar kelestarian sumberdaya alam yang ada pada daerah tersebut dapat terus dijaga.

Ekowisata berbasis konservasi merupakan pengembangan ekowisata yang menitikberatkan pada pola wisata ramah lingkungan, dimana pengembangan ekowisata harus mampu memelihara, melindungi, dan bertanggung jawab terhadap pelestarian alam. Kegiatan pengabdian masyarakat berupa sosialisasi tentang pengembangan ekowisata berbasis 
konservasi di Kampung Malagufuk ini berlandaskan pada prinsip dan kriteria pengelolaan ekowisata yang dibuat oleh BSN dalam SNI 8013:2014 tentang Pengelolaan Wisata Alam, berupa kelestarian fungsi ekosistem, kelestarian obyek daya tarik wisata alam, kelestarian sosial budaya, kepuasan, keselamatan, dan kenyamanan pengunjung serta prinsip manfaat ekonomi. Pengelolaan ekowisata yang berbasis konservasi juga harus memperhatikan keberlanjutan ekowisata dari aspek ekonomi, sosial, dan lingkungan, pengembangan institusi masyarakat lokal dan kemitraan, ekowisata berbasis masyarakat dan prinsip edukasi dan wisata alam. Persoalan yang paling mendasar adalah mengenai aksesibilitas menuju Kampung Malagufuk yang perlu mendapat perhatian serius dari Pemerintah Daerah agar pengembangan Kampung Malagufuk sebagai kawasan ekowisata dapat berjalan dengan baik.

Kegiatan akhir dari pengabdian masyarakat ini berupa penanaman bibit pohon sebagai bagian sekaligus bukti kepedulian terhadap konservasi. Kegiatan ini mendapat dukungan yang baik dari masyarakat setempat. Pemeliharan tanaman yang baru ditanam diserahkan sepenuhnya kepada masyarakat Kampung Malagufuk.

\section{DAFTAR PUSTAKA}

Anonim. 2009. Prinsip dan Kriteria Ekowisata Berbasis Masyarakat. Kerjasama Direktorat Produk Pariwisata, Direktorat jenderal Pengembangan destinasi Pariwisata, Departemen Kebudayaan dan Pariwisata dan WWF-Indonesia

Fandeli C. 2002. Perencanaan Kepariwisataan. Fakultas Kehutanan Universitas Gadjah Mada. Yogyakarta

Priono Y. 2012. Pengembangan Kawasan Ekowisata Bukit Tangkiling Berbasis Masyarakat. Jurnal Perspektif Arsitektur Volume 7 Nomor 1, Halaman 51-67. ISSN 1907 - 8536

Sastrayuda, G. S. 2010. Hand Out Mata Kuliah Concept Resort and Leisure, Strategi Pengembangan dan Pengelolaan Resort and Leisure. STBA-YAPARI-ABA Bandung Supriadi B, Nafi M., Roedjinandari N. 2017. Pengembangan Ekowisata Daerah. Buku Bunga Rampai Tahun 2017. Universitas Merdeka Malang. ISBN 978-602-6672-41-4

Qomariah L. 2009. Pengembangan Ekowisata Berbasis Masyarakat Di Taman Nasional Meru Betiri (Studi Kasus Blok rajegwesi SPTN I Sarongan). Departemen Konservasi Sumberdaya Hutan dan Ekowisata Fakultas Kehutanan Institut Pertanian Bogor. Skripsi 